\title{
SHORE PHASES OF THE GREEN RIVER FORMATION IN NORTHERN SWEETWATER COUNTY, WYOMING
}

\author{
By Wilmot H. Bradley
}

\section{INTRODUCTION}

\section{PURPOSE AND SCOPE OF THE REPORT}

For the last two years the writer has been engaged in a detailed study of the Green River formation and its oil shale. In order to arrive at an intelligent interpretation of this great series of lacustrine beds, the field study has been focused upon the marginal phases of the deposits and the associated formations, to determine, first, so far as possible from the geologic and biologic evidence recorded there, the environmental conditions that prevailed when these beds were laid down, such as the geologic history and physical configuration of the basin of deposition, the mode of filling, the sources and nature of the materials, and the climatic conditions under which the deposits accumulated. From the same evidence the writer has also endeavored to determine the kinds and relative abundance of both plant and animal life that existed in the Green River lake and on the adjacent land. Such evidence is fragmentary, as was to be expected, but it serves well as a basis for further study and interpretation.

The field studies have been supplemented by microscopic study of the oil shale and its microorganisms and of the associated rocks, such as the calcareous alga reefs and oolites. Much valuable information has also been obtained from an investigation of the processes of sedimentation that are taking place in modern inland lakes and the kinds of deposits that are produced by these processes. The interpretation of the organic shale and limestone must depend largely upon evidence of this kind.

This report records the results obtained from a field and office study of shore phases of the Green River formation on the northeastern margin of the Green River Basin and presents a brief summary of the writer's preliminary conclusions regarding the origin of the Green River oil shale.

\section{EARITER INVESTIGATIONS}

The area described in this report is part of the Green River district mapped and studied by F. M. Endlich. ${ }^{1}$ In this reconnaissance work the Wasatch, Green River,

1 U. S. Geol. and Geog. Survey Terr. Eleventh Ann. Rept., for 1877, pp. 131-139, pl. 3 (geologic map), 1879; Twelfth Ann. Rept., for 1878, pl. 3 (geologic map), 1883. and Bridger formations were differentiated and mapped. The accuracy of the mapping in part of the area here described was materially increased by the work of Schultz ${ }^{2}$ and Smith ${ }^{3}$ in 1907 and 1908.

\section{FIELD WORK}

In 1923 the writer, assisted by Carle H. Dane, mapped this area and studied particularly the phases of sedimentation in the Green River formation. The mapping was done largely by means of plane tables and telescopic alidades on a system of triangulation extended from a base line measured on a level-topped ridge just north of Steamboat Mountain. Isolated areal features were mapped in part on a topographic base furnished on a few of the General Land Office township plats and in part by means of pace traverses. The mapping was tied to section corners at many points.

The accompanying geologic map (Pl. LVIII) was compiled from the field sheets of Schultz, Smith, and the writer. Data obtained by Schultz and Smith were checked in the field and supplemented by new material. The location of the area is shown in Figure 7.

\section{ACKNOWLEDGMENTS}

The writer wishes to acknowledge the assistance of Mr. John W. Hay, of Rock Springs, Wyo., who supplied the party with saddle horses from his ranch, a few miles northeast of the area mapped. He also wishes to thank Mr. Banks W. Brady, of Eden, Wyo., for his cordial hospitality.

\section{TOPOGRAPHY}

A belt of shifting sand dunes from 4 to 8 miles wide extends from west to east across the southern part of the area and far out into the Red Desert Basin. Steamboat Mountain (altitude 8,630 feet above sea level) rises about a thousand feet above the general level of these dunes and is flanked on the east by a slightly lower escarpment, which faces southeast and extends northeastward beyond the limits of the area, and on the west by a similar escarpment, which faces southwest and extends northwestward. From these

\footnotetext{
${ }^{2}$ Schultz, A. R., Oil possibilities in and around Baxter Basin, in the Rock Springs uplift, Sweetwater County, Wyo.: U. S. Geol. Survey Bull. 702,, pl. 1, 1920; also unpublished field sheets.

${ }^{3}$ Smith, E. E., unpublished field sheets.
} 
escarpments the country slopes gently to the north. The western part of the area includes a small portion of the Bridger Basin.

Morrow Creek and its tributaries drain the western two-thirds of the area and Alkali Creek the eastern third. The Continental Divide separates these two drainage basins.

\section{STRATIGRAPHY}

The exposed rocks in this area belong to the Wasatch, Green River, and Bridger formations. Toward the north a part of the Green River formation is separated from the main body of that formation by a tongue of the Wasatch formation, which comes upper part consists largely of clay, which is predominantly drab but locally is banded with pink and maroon tints. Cross-bedded or massive lenticular beds of sandstone of stream-channel origin make up the remainder of the upper part.

The Cathedral Bluffs tongue of the Wasatch formation is more heterogeneous. It consists of clay ranging in color from green through greenish gray, gray, and buff to deep red; sandstone; sandy limestone; and locally thin calcareous alga reefs. Additional facts regarding these deposits are given under the heading "Source of sediments." Measured sections of the Cathedral Bluffs deposits are given on page 131 .

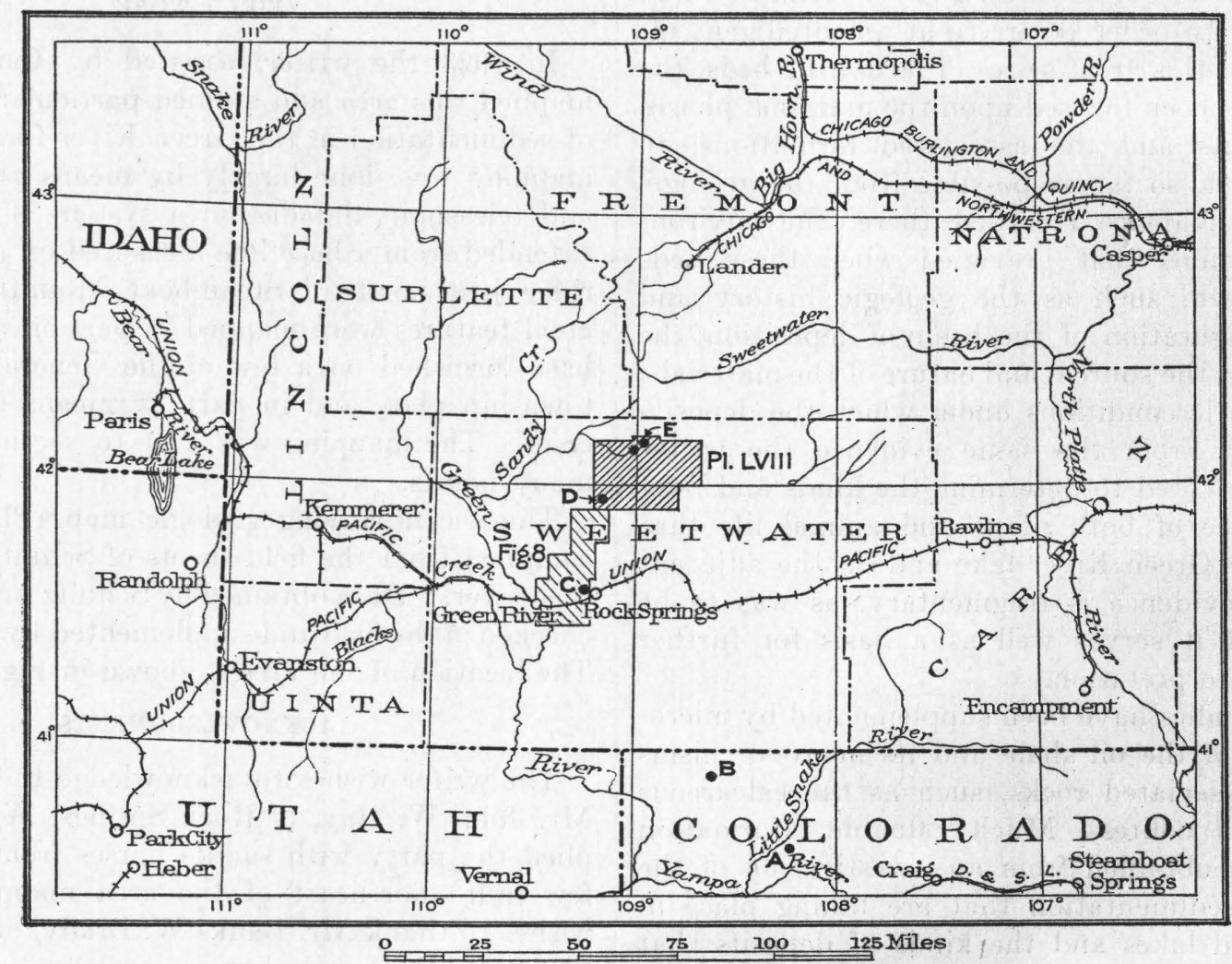

FIGURE 7.-Index map showing the location in northern Sweetwater County, Wyo., of the areas discussed in this report and locations in Wyoming and Colorado of measured sections given in Plate LIX

in from the north. The terms Tipton tongue of the Green River formation and Cathedral Bluffs tongue of the Wasatch formation have been applied to these tongues ${ }^{4}$ and will be used in this paper. Plate LIX shows the relations of these tongues to the other members of the Green River and Wasatch formations and to the overlying Bridger formation. Measured sections of the formations are given on pages 129-131.

\section{WASATCH FORMATION}

Only the upper 450 feet of the main body of the Wasatch formation is exposed in this area. This

${ }^{4}$ Sears, J. D., and Bradley, W. H., Relations of the Wasatch and Green River formations in northwestern Colorado and southern Wyoming: U. S. Geol. Survey Prof. Paper 132, pp. 98-99, 1924.

\section{GREEN RIVER FORMATION}

Tipton tongue.--Light-brown to buff finely laminated shale, ostracode-bearing limestone, oolite, and sandy limestone make up the bulk of the Tipton tongue of the Green River formation in this area. Sandstone, however, is locally conspicuous, either in persistent well-stratified beds or in massive or crossbedded lenses. Calcareous alga reefs are numerous in the Tipton tongue. At the base of the Tipton tongue throughout this area and beyond there is a very persistent limestone in which ostracodes are in places so abundant as to compose most of the rock. In the southwestern part of this area and to the south along White Mountain the Cathedral Bluffs 


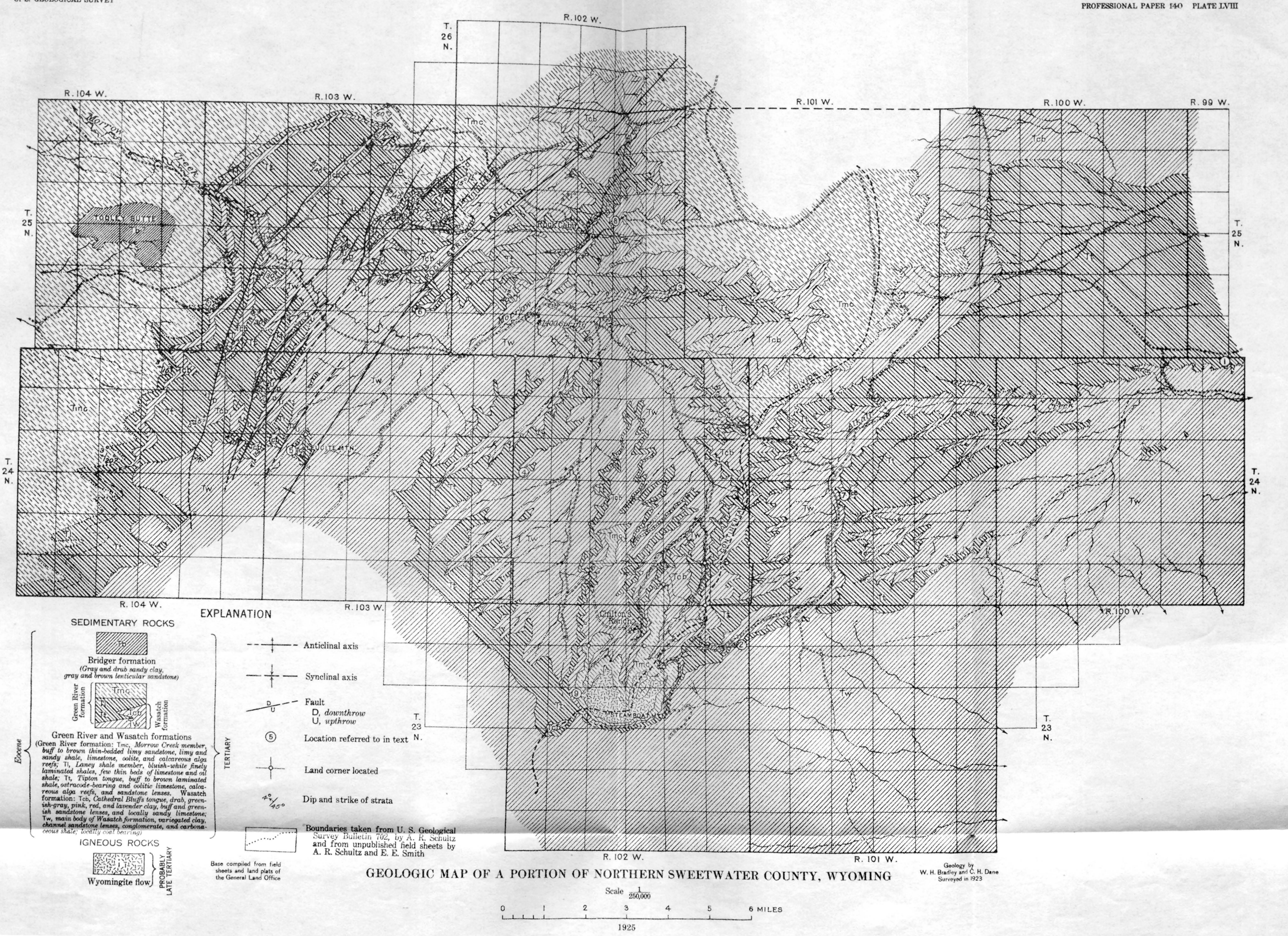




\section{U. S. GEOLOGICAL SURVEY}

A

Vicinity of

Little Snake River, Colo.

寽

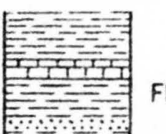

年,

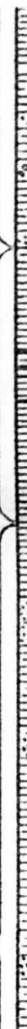

\section{Fluviatile and}

lacustrine

deposits

Lacustrine deposits
and oil shale

Lacustrine deposits
and oil shale

-

$-\ldots-\ldots-\ldots$

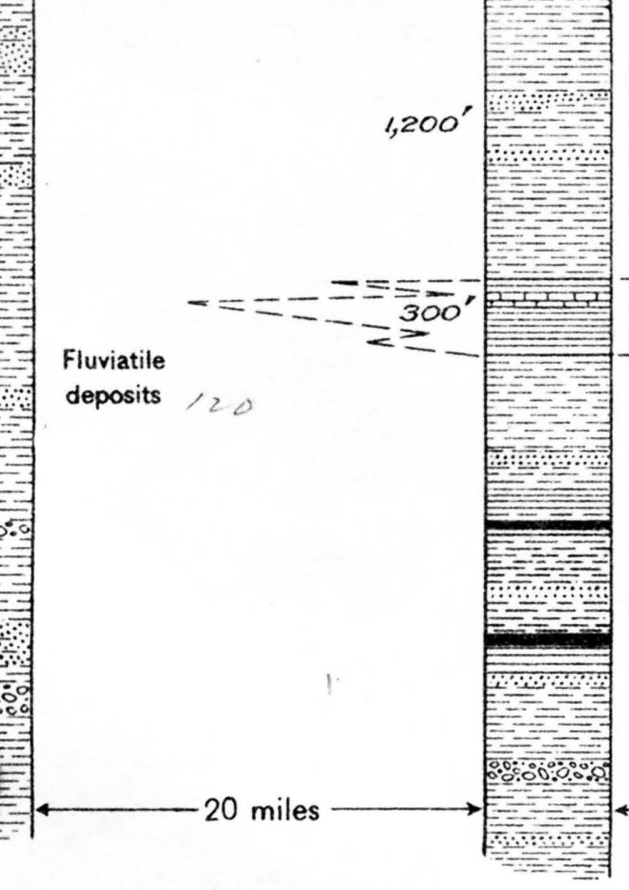

B

Vicinity of Lookout Mtn., Colo. 
tongue of the Wasatch formation is not represented, and the southern continuation of the Tipton beds is more appropriately termed the Tipton shale member of the Green River formation. Additional facts regarding the Tipton deposits are given under the heading "Source of sediments," and measured sections of the deposits are given on pages 129 and 130 .

Laney shale member.-In this area and in White Mountain, to the southwest, the deposits overlying the Tipton tongue belong to the Laney shale member, which here consists entirely of finely laminated shale, oil shale, and limestone. The rocks of this member without exception weather bluish white and make a conspicuous feature of the landscape. (See Pl. LX, $A$.) Their relations to the underlying Tipton tongue and the Cathedral Bluffs tongue of the Wasatch formation are shown in Plate LIX. The thickness of the beds is stated under "Source of sediments," and the lithology is further described under "Origin of Green River oil shale."

Tower sandstone lentil and Morrow Creek member.In this area the Laney shale member thins and disappears completely toward the north and east. The overlying member of the Green River formation, which Powell ${ }^{5}$ called the "Upper Green River," continues eastward to Steamboat Mountain and northeastward to Oregon Buttes and Continental Peak, beyond which it was not traced. In Powell's definition of the "Upper Green River" he included a basal sandstone, which he designated the Tower sandstone, and the 'overlying plant beds. The Tower sandstone was so named because it forms the tops of the weathered rock masses known in the vicinity of Green River as The Towers. (See fig. 8 and Pl. LX, B.) It is lenticular and is therefore herein designated the Tower sandstone lentil of the Green River formation. It consists of cross-bedded and massive beds of medium to coarse grained brown sandstone which is firmly indurated by a limonitic cement. The Tower sandstone is not present in the area described in this report but occurs farther south, in the vicinity of the town of Green River, Wyo. In the northern part of Sweetwater County it appears to be replaced by the lower part of the plant-bearing beds herein designated the Morrow Creek member of the Green River formation, because of their extensive exposures in the valley of Morrow Creek. (See Pl. LIX, which illustrates the lenticular nature of the Tower sandstone and its relations to the Morrow Creek member.) The Morrow Creek member is a distinct lithologic unit easily traceable from this area southward along the top of White Mountain to the Union Pacific Railroad and thence westward to Green River. It consists largely of buff sandy limestone and buff sandstone, which contrast rather sharply with the underlying

$\checkmark$ Powell, J. W., Report on the geology of the eastern portion of the Uinta Mountains, p. 45, U. S. Geol. and Geog. Survey Terr., 2d div., 1876. bluish-white Laney shale member. Poor bedding and chippy fragments are characteristic of the exposures of these beds. In addition to the sandstone and limestone there is a small amount of light-brown paper shale and an occasional alga reef or pisolite. Locally plant impressions are abundant. The Morrow Creek member ranges in thickness from 100 to 300 feet. A measured section of it is given on page 131.

\section{BRIDGER FORMATION}

The Bridger formation occupies but a small portion of this area. It consists of poorly consolidated coarsegrained sandstone and dull-gray sandy clay. These beds weather into pronounced badland forms.

\section{IGNEOUS ROCKS}

Steamboat Mountain is capped by two flows of a unique leucite-rich lava called wyomingite. According to Kemp and Knight ${ }^{6}$ the rock consists principally of leucite and phlogopite, together with a small amount of diopside and hornblende in a gray-green glass. The accessory minerals are rutile and apatite.

\section{STRUCTURE}

The structure of this area is determined by the Rock Springs anticline, the axis of which passes through Leucite Mountain. The anticline plunges rapidly to the northeast and loses its identity just north of this area in a very shallow syncline, which is roughly parallel to the major axis of the Wind River Mountains.

Dips of $1^{\circ}$ to $2^{\circ} \mathrm{NE}$. prevail east of the anticlinal axis. On the west flank the dips are generally steeper and the rocks are displaced by a zone of nearly parallel normal faults that has the same trend as the anticlinal axis. The faults are marked by rather prominent scarps, a fact which perhaps indicates a recent origin.

\section{SOURCE OF SEDIMENTS}

At the base of the Tipton tongue throughout this area and extending beyond the area as far south as Fourteenmile Spring, in sec. 33, T. 21 N., R. 105 W., there is a limestone of a surprisingly persistent nature. It varies in thickness from place to place but is nowhere entirely absent. Most commonly it is oolitic or even pisolitic and always carries a great abundance of ostracodes (Pl. LXI, $B$ ), locally so many that they form the greater part of the rock. In almost constant association with these features are Goniobasis shells and more rarely Unio shells.

Above this remarkably persistent basal limestone there is a noticeable differentiation in the lithology of the Tipton tongue in different parts of the area. Southeast of a diagonal line drawn through secs. 1 and 31, T. 24 N., R. 102 W., the Tipton tongue con-

${ }^{6}$ Kemp, J. F., and Knight, W. C., Leucite Hills of W yoming: Geol. Soc. America Bull, vol. 14, p. 326, 1903. 


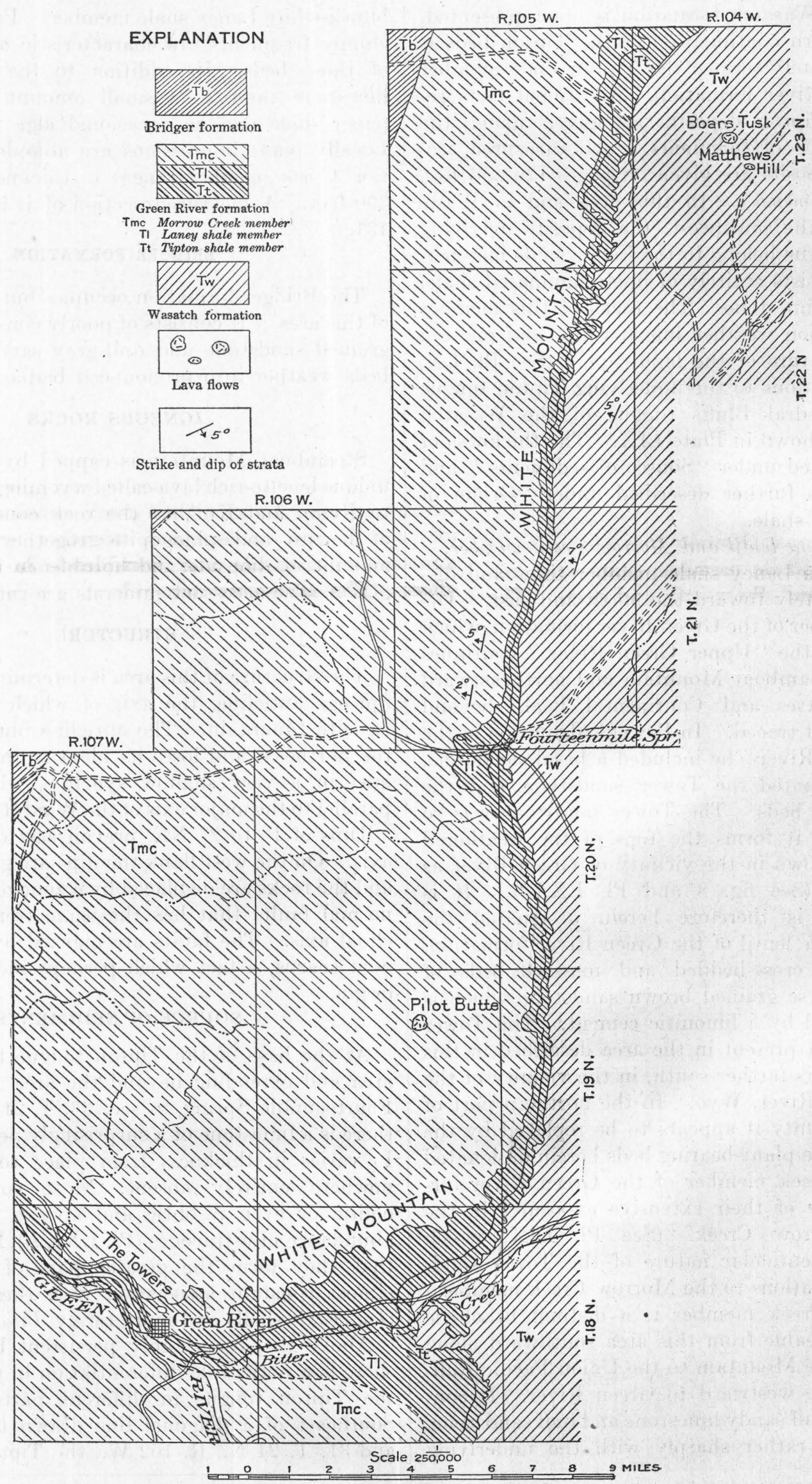

FIGURE 8.-Geologic map showing the southern extension of the Green River and Wasatch formations in White Mountain, Wyo., and the type locality of the Tower sandstone lentil. (From U. S. Geol. Survey. Bull. 702, pl. 1) 


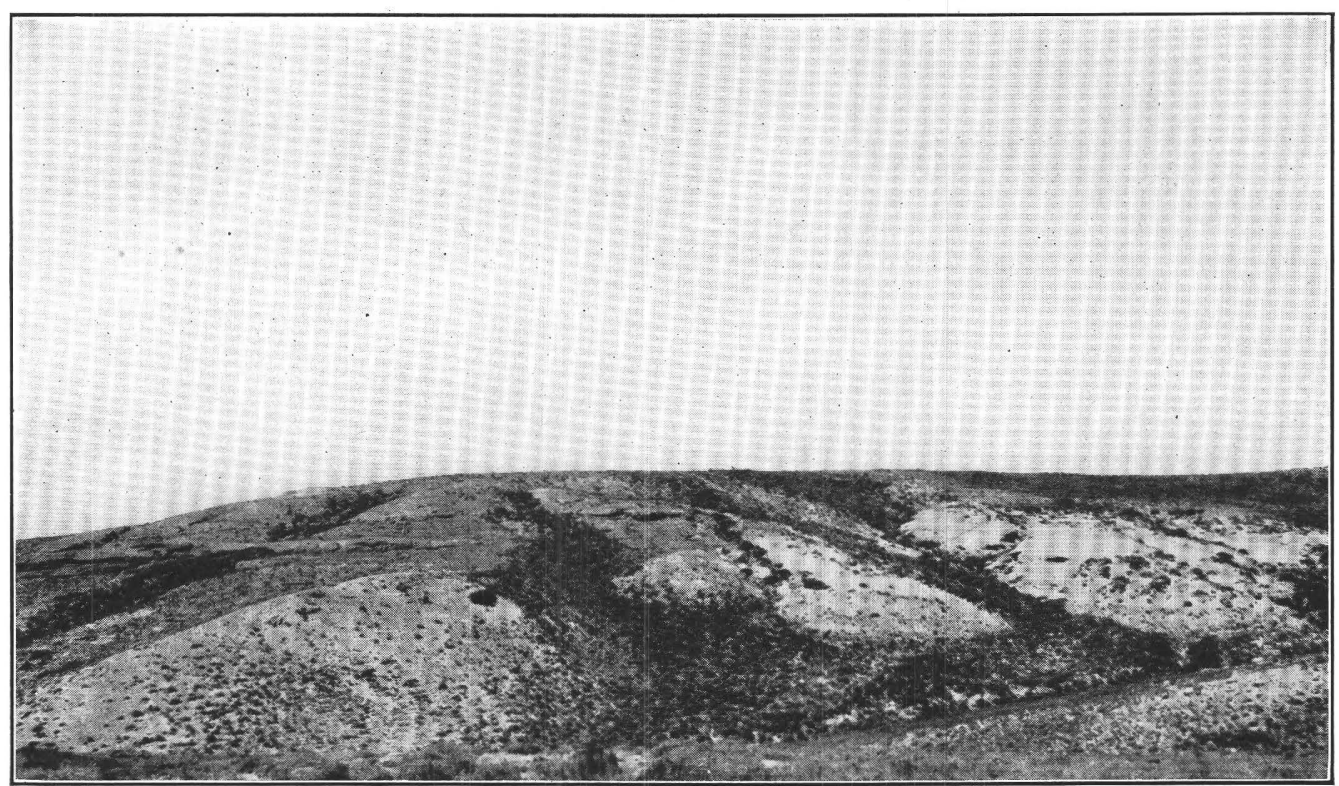

A. WHITE LANEY SHALE MEMBER OF GREEN RIVER FORMATION FAULTED DOWN AGAINST TIPTON TONGUE OF THE SAME FORMATION IN NORTHWEST CORNER OF SEC. 1, T. 24 N., R. 104 W., WYO.

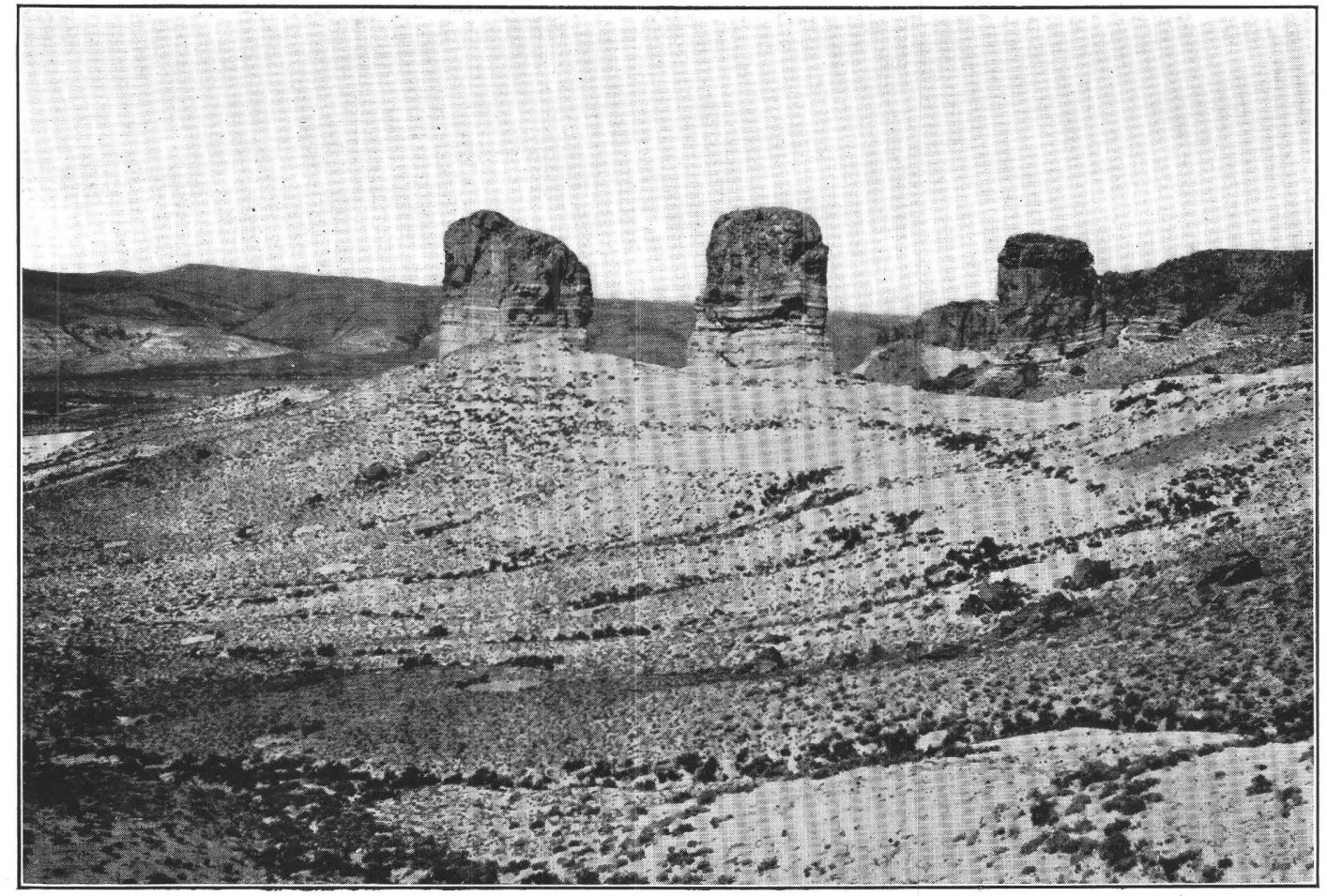

B. REMNANTS OF TOWER SANDSTONE LENTIL OF GREEN RIVER FORMATION CAPPING “THE TOWERS" ABOUT A MILE NORTHWEST OF GREEN RIVER, WYO. 


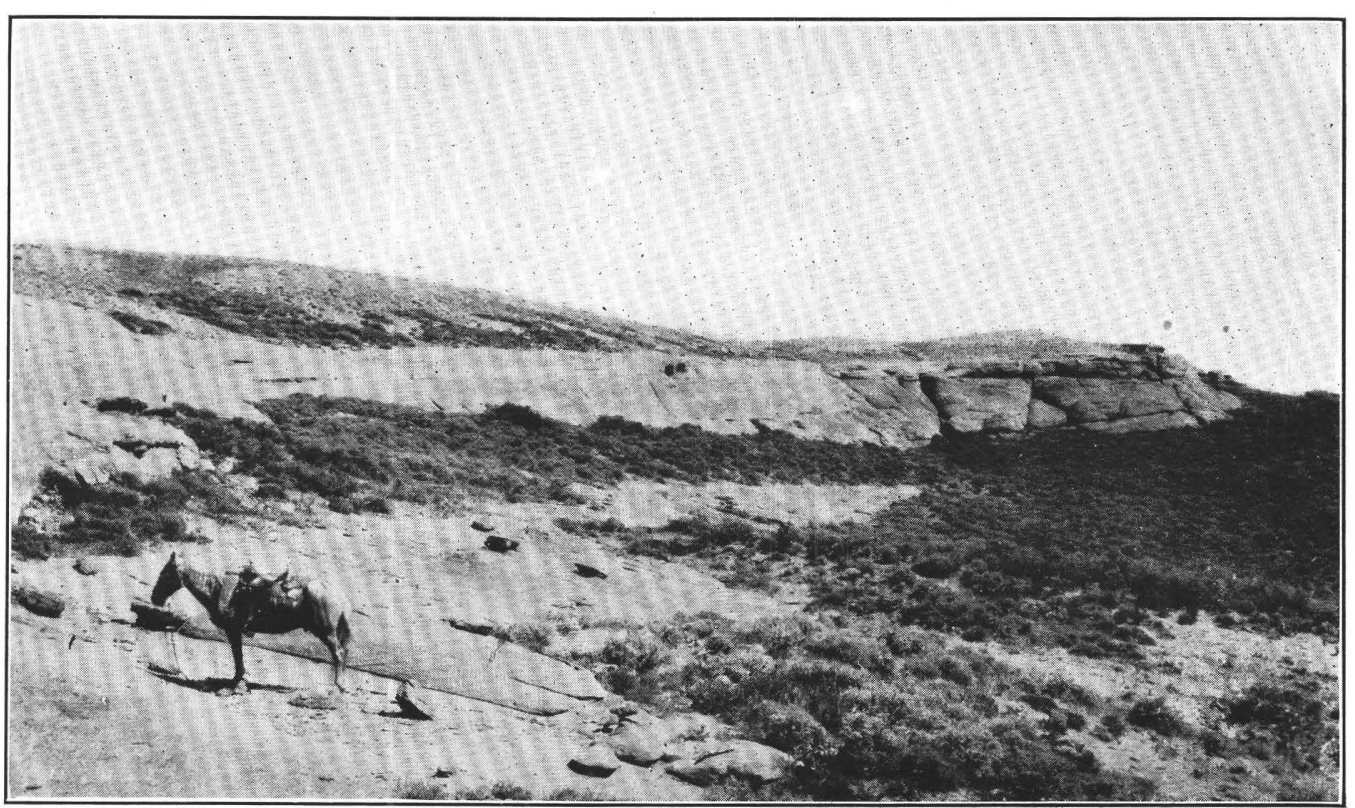

A. LARGE SANDSTONE LENS IN TIPTON TONGUE OF GREEN RIVER FORMATION IN SEC. 1, T. 24 N., R. 104 W., WYO.

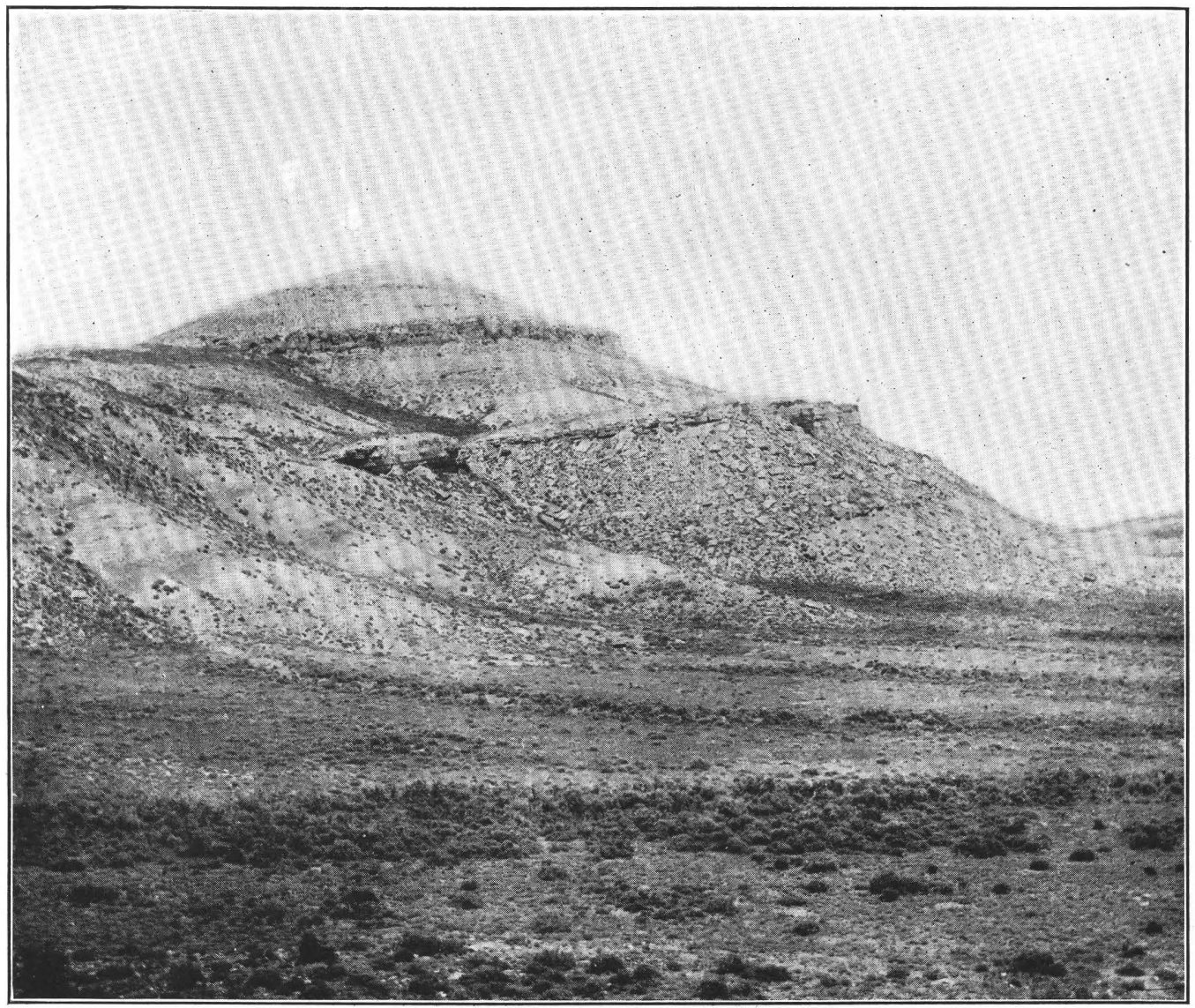

B. LARGE BASAL OOLITIC LIMESTONE AND HIGHER SANDSTONE LENSES OF TIPTON TONGUE OF GREEN RIVER FORMATION FAULTED DOWN AGAINST VARIEGATED CLAY OF WASATCH FORMATION IN E. $\frac{1}{2}$ SEC. 22 , T. 25 N., R. 103 W., WYO. 


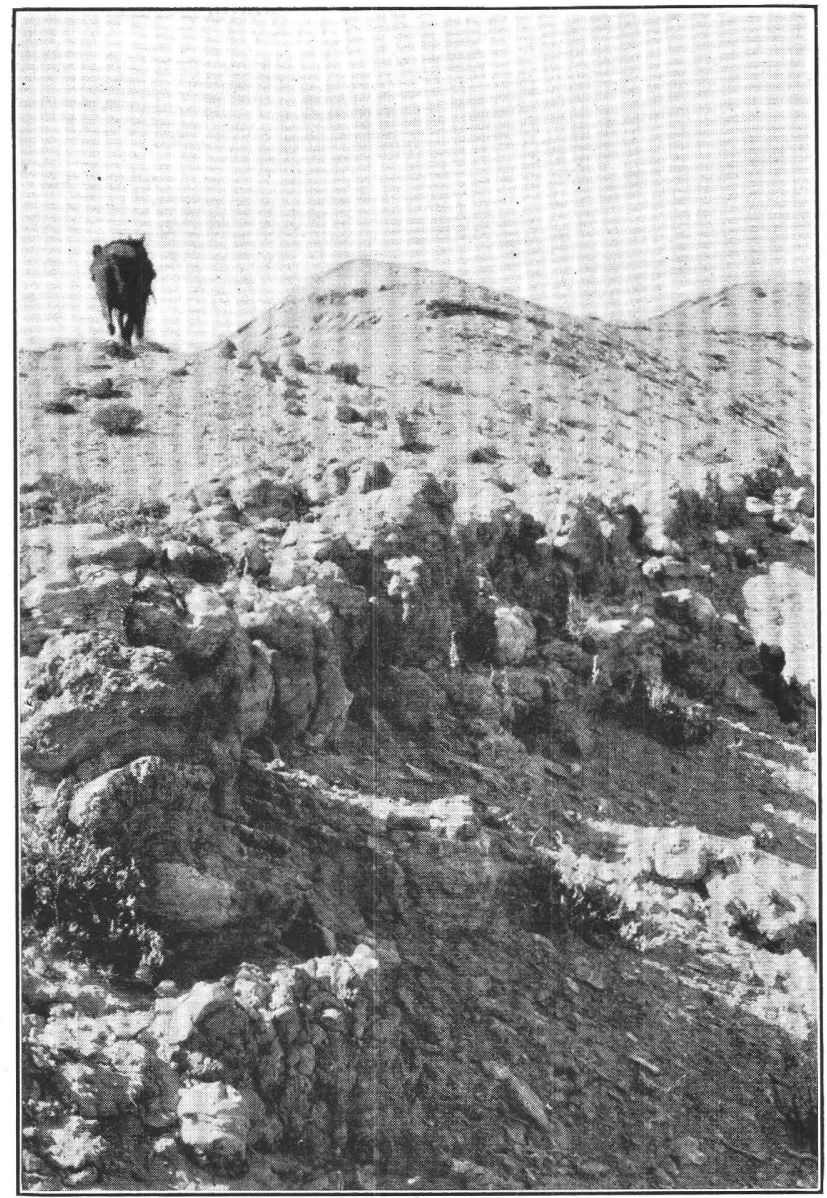

1. LARGE CALCAREOUS ALGA REEF NEAR TOP OF GREEN RIVER FORMATION IN N. $\frac{1}{2}$ SEC. 12, T. 23 N., R. 102 W., WYO.

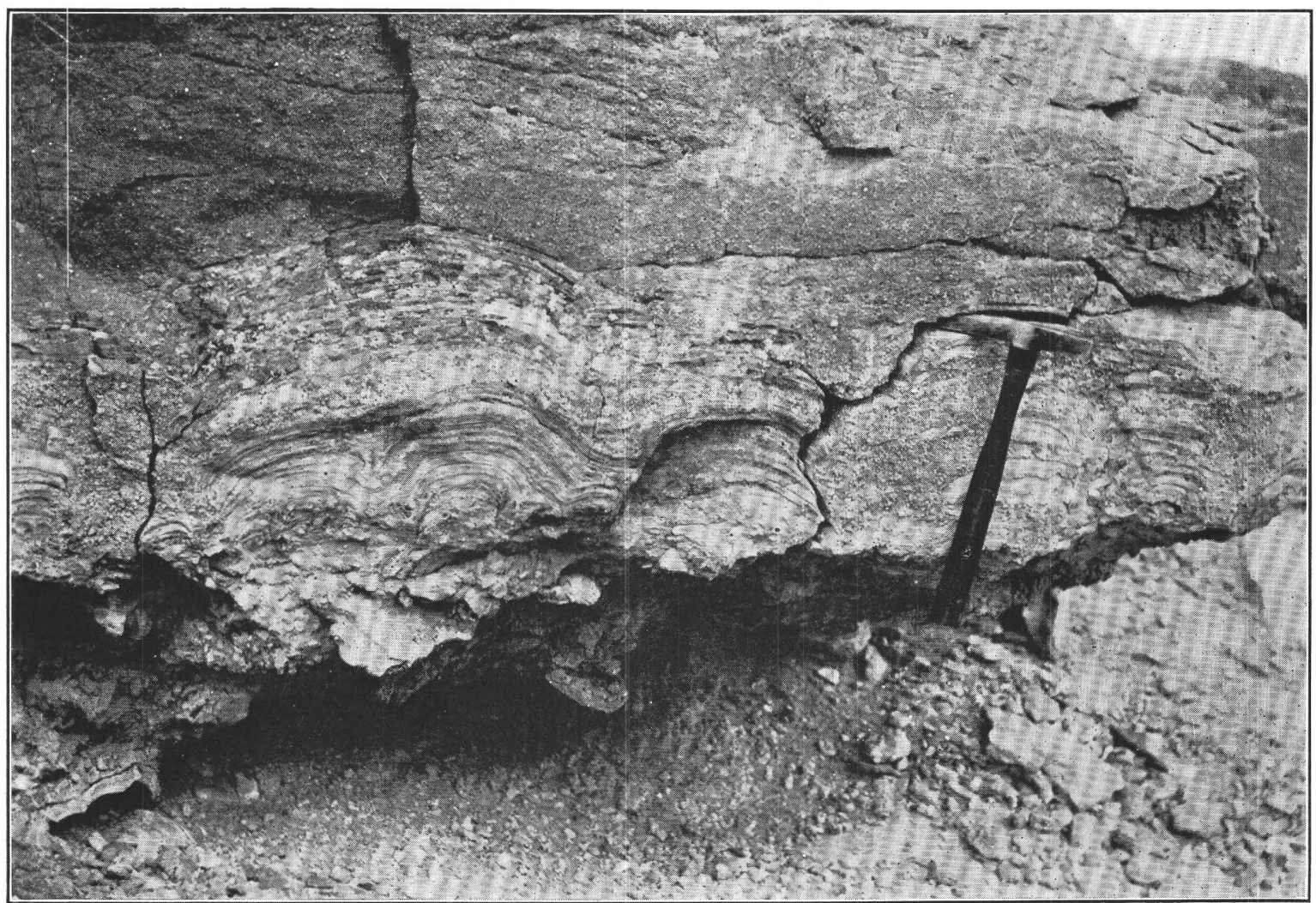

B. CAlCareous alga ReEF intimately associated with Oolitic and Pisolitic Limestone AT BaSE OF TIPTON TONGUE OF GREEN RIVER FORMATION IN SEC. 22, T. 25 N., R. 103 W., WYO.

The lower part of the reef is broken and recemented by oolitic limestone 
sists of finely laminated shale, ostracode-bearing limestone, limestone, oolite, and alga reefs but no sandstone. Northwestward from that line sandstone becomes more and more abundant. Near the line the sandstone is usually limy, micaceous, very fine grained, and in thin, relatively persistent beds. Rarely this fine limy sandstone shows cross-bedding on a minute scale.

Toward the northwest the sandstone becomes more massive or more cross-bedded and the sand grains become larger until in local lenses the pebbles are as much as half an inch in diameter. These pebbles and coarser sand grains, largely of quartz and feldspar, are either sharply angular or only slightly rounded. The feldspar grains are commonly glassy and have bright cleavage surfaces. In this direction also the sandstone becomes more and more lenticular until in the western part of the area the lenses have all the features characteristic of stream-channel deposits (PI. LXI, $A$ ).

In White Mountain, southwest of this area, there is a similar lithologic change in the Tipton northward from Fourteenmile Spring. (See fig. 8.)

The numerous stream-channel deposits become evenly bedded, finer grained, and thinner to the south and southeast and eventually grade into finely laminated shale. These facts clearly indicate that the source of the sediments was to the north, and as they pass from fluviatile to lacustrine sediments in a general southeasterly direction it seems probable that the trend of the shore line was northeastward in this locality. The shore line could not be located accurately, because of insufficient exposures and because it evidently migrated with changes in water level, but it probably should be placed where crossbedding in the sandstone lenses becomes reduced greatly in scale and the greater portion of the sand assumes a distinct and fairly regular bedding. It was found in the field that where the sandstone assumes a lacustrine aspect the lime content increases materially.

It is probable that the Wind River Mountains, about 20 miles north of this area, constituted the land mass from which streams carried these sediments. The arkosic nature of the stream-channel deposits as well as the sharp angularity and freshness of the individual grains is in harmony with this suggestion, for the deeply dissected core of the Wind River Range consists of coarsely crystalline granite.

That the Wind River Mountains were sufficiently high above the basin of deposition to furnish abundant rock waste in Eocene time seems amply proved by the studies of Blackwelder, ${ }^{7}$ and it does not appear necessary to restate the evidence in this paper.

\footnotetext{
${ }^{7}$ Blackwelder, Eliot, Post-Cretaceous history of the mountains of central-western Wyoming: Jour. Geology, vol. 23, pp. 97-117, 193-217, 307-340, 1915.
}

Additional evidence that the source of the sediments was to the north is obtained from an examination of the relations between the Wasatch and Green River formations in this area. These formations interfinger in such a way that the lacustrine sediments of the Green River formation either thin or disappear entirely toward the north, whereas on the other hand the fluviatile sediments of the Cathedral Bluffs tongue of the Wasatch formation thin or even disappear to the south.

The Laney shale member of the Green River formation thins northward from about 200 feet in sec. 31, T. 24 N., R. 104 W., to less than 50 feet, and finally by the introduction of more and more thin fingers of green clay it loses its lithologic identity and passes over in sec. 3, T. 25 N., R. 102 W., into the typical fluviatile deposits of the Cathedral Bluffs tongue of the Wasatch formation. Throughout the remainder of the area the Morrow Creek member of the Green River formation, which itself becomes sandy and thins northward from more than 300 feet to about 100 feet in Oregon Buttes, in sec. 12, T. 26 N., R. 101 W., rests directly upon the Cathedral Bluffs tongue.

Near the head of Alkali Brook the Cathedral Bluffs tongue is about 200 feet thick, but at Steamboat Mountain it is only a little more than 100 feet thick. A more striking example, however, is to be seen in the western part of the area, where the same tongue of fluviatile clay thins from 200 feet in the north until it pinches out completely between the Laney shale member and Tipton tongue of the Green River formation about 16 miles to the southwest. (See Pl. LIX.)

\section{BIOLOGIC EVIDENCE OF SHORE PHASES}

From the preceding discussion of the larger relations of the several formations and their lithologic character it is clear that these rocks represent the marginal phases of lacustrine deposits and the closely related shore and fluviatile deposits. Many of the life forms associated with these phases of deposition are preserved in the deposits and furnish considerable information concerning the physical and biologic conditions under which the sediments were laid down. In addition they may serve as criteria for the recognition of lake-margin deposits in other areas where the lithology alone is not distinctive.

Calcareous alga reefs, oolites, pisolites, and ostracode-bearing limestones are present in abundance in the Tipton tongue and Morrow Creek member of the Green River formation in this area and deserve consideration in such a study of lacustrine sediments because of their value as indicators of the physical conditions that attended sedimentation. (See Pl. LXII, A.)

Calcareous alga deposits of recent origin variously described as water biscuit, nodular marl, algoid lake balls, or marlyte are evidently the modern representa- 
tives of the fossil alga reefs. An examination of the mode of occurrence of some of these recent forms is instructive. Pollock ${ }^{8}$ describes algal pebbles in a Michigan lake as being abundant and more or less grown together in the shallow water near shore and becoming smaller and less numerous as the water deepens away from shore. Blatchley and Ashley, ${ }^{9}$ in discussing the deposition of marl in James Lake, say: "Along much of the shore of the lake, particularly in the shallower water, the marl is markedly concretionary on top and often for 3 or 4 feet down." Clarke, ${ }^{10}$ Powell, ${ }^{11}$ and others have emphasized the rapidity of growth of such deposits in very shallow lake margins. Calcareous reefs, very probably of the same origin as the fossil alga reefs in the Green River formation, were formed on the wave-cut terraces in Lake Lahontan ${ }^{12}$ when the lake was deep and of broad extent.

It is perhaps germane to note here that at several localities the alga reefs of the Green River formation are broken as if by wave action and that the broken fragments are at some places associated with rather coarse sand and at others with fine limy sand that shows abundant mud curls. Many of the fossil alga reefs in this area are immediately overlain by clean, well-sorted medium-grained sand, which is locally unconsolidated. Such a deposit of sand at least suggests the effects of the currents or waves common in shallow water. Again, some of the algal deposit was formed around logs, and in sec. 23, T. 25 N., R. 103 W., near the top of the Tipton tongue of the Green River formation, there are a large number of hollow cylinders of algal limestone 1 to 2 feet in outside diameter, 8 to 10 inches in inside diameter, and 6 to 8 feet in length. The inner surface of these log cases exhibits undoubted woody structure. Branching is also common in them.

The writer believes that the oolites and pisolites of the Green River formation in this area were deposited through the agency of microscopic plants, either algae or bacteria, and therefore that they were formed under physical conditions at least not widely divergent from those which produced the alga reefs. (See Pl. LXII, B.) In Ore Lake, Mich., Pollock ${ }^{13}$ observed vast numbers of minute spherical or subspherical grains, virtually a mixed oolite and pisolite, forming in the shallow lake margins. Pisolite is now forming at the shores of Pyramid Lake, Nev. ${ }^{14}$ a lake which has less than 0.5 per cent of solids in solution. The formation of oolite

8 Pollock, J. B., Michigan Acad. Sci. Twentieth Ann. Rept., p. 249, 1918.

B Blatchley, W. S., and Ashley, G. H., The lakes of northern Indiana and their associated marl deposits: Indiana Dept. Geology and Nat. Resources Twenty-fifth Ann. Rept., p. 81, 1900.

10 Clarke, J. M., The water biscuit of Squaw Island, Canandaigua Lake, N. Y.: New York State Mus. Bull. 39, vol. 8, pp. 195-198, 1900.

11 Powell, C., Observations on some calcareous pebbles: Minnesota Bot. Studies, vol. 3, pp. 75-76, 1903.

12 Russell, I. C., Geological history of Lake Lahontan: U. S. Geol. Survey Mon. 11, p. 191,1885 .

13 Op. cit., p. 249.

14 Russell, I. C., op. cit., p. 168. on the shores of salt lakes and on marine beaches is well known. Nearly all of the recent oolite that is similar to the fossil oolite of the Green River formation in both microscopic and megascopic features is being formed either at or very close to the strand line.

In addition to the calcareous alga reefs and relatively abundant oolite and pisolite in the lacustrine deposits of this area there are numerous beds composed almost entirely of ostracode shells. Only two of the several genera of ostracodes have been identified, and they both have a rather general distribution in depth and salinity of water, so that in themselves they are of little value as indicators of the physical conditions of the lake. So abundant are these shells, however, that in many places they form loosely consolidated beds from 1 to 3 feet thick. Interbedded with such pure shell limestones are large quantities of soft, finely laminated limy shale in which ostracode valves are conspicuous constituents. Such vast numbers of these organisms must have lived in the shallow, welllighted, well-aerated, algae-rich margins of the water body in which these sediments were deposited.

In association with the ostracode-bearing limestone and oolite, other evidence of the same marginal conditions is found in the larval cases of trichopterous insects. These insects require considerable oxygen in the larval stage as well as such microscopic food plants as abound in shallow, well-lighted waters. The cases of these insect larvae were constructed of ostracode valves. Two new species of these fossil insects have been described by the writer. ${ }^{15}$

Plant remains, such as the impressions of Equisetum stems and the leaves of higher plants, are very common in the Morrow Creek member of the Green River formation and are of sporadic occurrence in the Tipton tongue. A few thin beds of carbonaceous shale composed largely of carbonized plant remains also occur in the Green River formation of this area. The floral evidence from these rocks thus appears to be in accordance with the hypothesis that they were deposited near the margins of the ancient lake.

In addition to the evidence already stated, there exists some more or less fragmentary evidence-for example, in sec. 30 , T. 25 N., R. 101 W., the mingling of the bones of aquatic and terrestrial vertebrates in a thin but persistent grit which the writer believes is a beach deposit in the Tipton tongue of the Green River formation. The bones associated there are the teeth and vertebrae of fish and fragments identified by J. W. Gidley as belonging to Parameryx, a small camel. Near the top of both the Tipton tongue and the Morrow Creek member of the Green River formation petrified wood is rather abundant. The value of petrified wood as an indicator of lake-margin conditions, however, is rather doubtful.

${ }_{15}$ Bradley, W. H., Fossil caddice-fly cases from the Green River formation of Wyoming: Am. Jour. Sci., 5th ser., vol. 7, pp. 310-312, 1924. 


\section{ORIGIN OF THE GREEN RIVER OIL SHALE}

\section{OIL SHALE OF THE LANEY SHALE MEMBTR}

Description of the Laney shale member of the Green River formation has purposely been deferred up to this point, because its deposition was evidently attended by physical conditions that differed from those which produced the underlying and overlying sediments. This member consists entirely of exceedingly fine-grained sediments which contain in addition to the clastic mineral matter varying proportions of organic matter. The organic content ranges from almost none in the barren limy shale to as much as 36 per cent in the richest oil shale found in this area. On distillation this rich shale yielded oil at the rate of 35.5 gallons to the short ton. All gradations between these two extremes in organic content exist, but the greater part of the shale in the Laney shale member in this area is relatively poor in organic matter. The sample that yielded 35.5 gallons of oil to the ton came from a thin bed of oil shale in sec. 2, T. 24 N., R. 104 W. North and east of this place the organic content decreases rapidly, and for the last several miles of the Laney shale member all the shale and limestone is quite barren of organic matter. The physical conditions that attended the deposition of the barren part of the Laney shale member of the Green River formation were probably similar to those that attended the deposition of the Tipton tongue of the Green River formation already described. The mode of origin of that part of the Laney shale member which contains an appreciable content of organic matter involves the more specific question of the origin of the oil shale.

\section{PRELIMINARY CONCLUSIONS}

Regarding the conditions of deposition of the Green River oil shale, the preliminary conclusions from the field and microscopic study of the last two years on the oil shale and microscopic flora of the Green River formation may be stated briefly at this time. The detailed evidence upon which these conclusions are based will be presented in another paper, the completion of which awaits more extended field observation and microscopic study.

\section{ORGANIC CONSTITUENTS}

Evidence of several kinds leads the writer to believe that the dominant part of the organic matter in the oil shale of the Green River formation consists of the remains of planktonic organisms that lived in the surface waters of the ancient lake. Probably most of these organisms, which after death accumulated on the lake bottom as a putrescent ooze, were microscopic plants. Many of the living planktonic algae are rich in a fatty or oily substance which is the product of their metabolism and may also serve in part for buoy- ancy. There is considerable evidence to indicate that the Eocene representatives of the plankton flora were similar in this respect. As the zooplankton depends largely upon the phytoplankton for food, there was very probably an abundant microscopic fauna, but it remains to be demonstrated to what extent it contributed to the organic ooze that became oil shale when it was subsequently lithified. The only microscopic animal remains so far known in the Green River oil shale are very rare fragments of insects. In the associated beds, however, a large invertebrate and vertebrate fauna has been found.

Pollen and spores constitute a much smaller part of the organic matter than the remains of plankton, and as they were transported by the wind they are irregularly disseminated through the deposit. Nevertheless they produce oil upon distillation, and consequentiy where they occur in abundance the shale is enriched.

The more highly organized plants that grew on the land adjacent to the shores and the larger aquatic plants that inhabited the shallow lake margins contributed very little to the organic shale. Aside from the pollen and spores which these plants produced they are represented in the oil shale by only scattered fragments of a lignified or suberized cell, or group of cells. Such fragments of higher plants are usually somewhat strongly humified or even carbonized and yield little if any oily distillate. Precipitated humin acid, also poor in oily distillates, is apparently inconspicuous in the Green River oil shale. Under certain conditions in small ponds and in the shallow margins of large lakes a type of oil shale has formed which contains in addition to the plankton material considerable humified débris and probably also precipitated humin acid, both of which were derived from the more highly organized land and aquatic plants. Such an oil shale is likely to be of only local occurrence and therefore of only small commercial importance. An oil shale of this kind occurs in the Fuson formation near Cambria, Wyo.

The evidence thus far accumulated by the writer suggests that there are two entirely distinct types of oil shale, the characteristics of which are determined largely by the depth of water in which the original deposit formed.

That type of oil shale which in the Green River formation of both the Green River and Uinta basins yields the most oil upon distillation appears to have resulted from a periodic concentration of organic matter due to a very pronounced reduction in volume of the water body. This shale is characteristically black on the fresh surface and weathers bluish white. The lake or lakes, as the case may be, in which this oil shale formed were probably less than 100 feet in depth at the initiation of any given cycle and supported a luxuriant plankton flora and fauna. It 
seems probable that the reduction in depth and volume of the lakes was accompanied by stagnation and an increase in temperature of the water, factors both of which would stimulate a vastly greater production of the plankton and hence increase the volume of the organic ooze. The facts indicate that such periodic reductions of volume accompanied by the augmented production of plankton proceeded in most places until there remained only a sirupy or gelatinous mass of putrescent organic matter on the bottoms of the lake basins.

Desiccation appears to have been the final phase of some of these periodic reductions in volume, for some of the oil shale is mud cracked and brecciated, and in places the bedding planes are studded with molds of salt crystals. In the samples of this brecciated oil shale so far examined no pyrite has been found, but many of the other rich oil shales of otherwise similar character contain pyrite in varying amounts disseminated in minute grains and blebs. When these shales were formed reducing conditions evidently persisted until lithification occurred, whereas the brecciated shale was probably exposed for a short time at least to oxidizing conditions. The absence of pyrite in the brecciated shale, although not conclusive, is suggestive of exposure to air.

Bacterial decomposition of the organic matter must have been effectively checked prior to lithification. It is not yet known whether this putrefactive decomposition was inhibited by the concentration of inorganic salts in solution or the concentration of toxins in the form of organic acids (the products of bacterial activity) or by the paucity of available water necessary to continued bacterial life. It seems probable that more than one of these factors or perhaps all acted simultaneously to produce the aseptic state necessary to the preservation of the organic matter.

The other type of oil shale - the ordinary lean and commonly limy shale of the Green River formation-as a rule yields an appreciably smaller quantity of oil to the ton on distillation. It is usually light brown or even dark chocolate-brown but rarely if ever black, and it weathers buff rather than bluish white. The intimate and consistent association of remains of freshwater aquatic plants, insect larvae, crustaceans, and fish with this lean oil shale suggests that it accumulated in water bodies of a more permanent nature but at the same time of moderate depth, perhaps not exceeding 60 feet. This shale, then, probably derived its organic content from the accumulation on the bottom of planktonic organisms similar to those which constitute the water bloom of existing fresh-water lakes.

The cessation of bacterial activity in such an organic ooze would be dependent only upon the exclusion of sufficient water and oxygen for putrefaction, which would result from the compression due to the weight of later deposits. It is significant that the organic matter in this generally lean oil shale has been completely disorganized, presumably through the activity of bottom-dwelling organisms, such as certain fish, crustaceans, and nematodes, and of bacteria and fungi, whereas in the richer type of oil shale many of the microorganisms, spores, and pollen grains that go to make up the organic part of the shale have retained their original form and a few of them even their internal structure.

Conditions approaching those outlined above accompanied the deposition of part of the Tipton tongue of the Green River formation in this area and resulted in several beds of very low grade papery oil shale. These shales will yield less than 10 gallons of oil to the short ton on distillation. In other parts of the Green River Basin the Tipton tongue of the Green River formation contains oil shale of a higher grade.

Whatever kind of organic matter accumulated on the substratum, it was subjected to a more or less thorough but slow putrefaction, in which bacteria, saprophytic fungi, and similar microorganisms effected a selective decomposition, the more cellulosic parts of the organisms and plant parts being removed and the fatty, waxy, and resinous parts remaining as resistant matter, to be later lithified and thus preserved as oil shale.

\section{CHEMICAL CHANGES}

The original organic ooze has undergone complex and probably numerous chemical changes since its accumulation on the lake bottoms. Very little is known regarding these changes except that the trend was evidently toward the elimination of oxygen with a corresponding relative increase in hydrogen and carbon. Part of this change may have occurred during the accumulation of the dead organisms on the substratum, through the agency of bacteria. The remainder of the series of changes may have occurred very gradually subsequent to lithification as purely chemical reactions, perhaps assisted or even entirely controlled by the presence of inorganic matter in a colloidal state.

E. T. Erickson, of the United States Geological Survey, is at present engaged in a protracted study of the chemistry of these complex changes. Lacustrine organic oozes form the starting point of some of these investigations.

\section{MINERAL CONSTITUENTS}

Concomitantly with the accumulation of the organic constituents occurred the deposition of varying amounts of finely divided aluminous material, calcium carbonate, and minute particles of quartz. In the Laney shale member of the Green River formation the quantity of calcite far exceeds that of the other mineral constituents. The calcite is distributed 
pretty uniformly through the shale in very fine particles and may have been deposited indirectly through the agency of bacteria. According to Kellerman ${ }^{16}$ the precipitation of calcium carbonate may take place "by the combined action of ammonia, produced by bacteria either by the denitrification of nitrates or by the fermentation of protein, together with carbon dioxide, produced either through the respiration of large organisms or the fermentation of carbohydrates by bacteria." There was certainly sufficient ammonia and carbon dioxide in association with the putrefying plant and animal matter at the bottom of the Green River lake to effect such a precipitation, if there was an adequate supply of lime salts. Kellerman's experiments ${ }^{17}$ showed that ordinary crystals of calcite could be produced by a growth of mixed cultures of bacteria in either salt or fresh water.

\section{CLIMATE}

The climate that attended the deposition of the Green River formation must have been warm and moist enough to support a luxuriant vegetation and yet of such a seasonal nature that it alternately favored and inhibited the growth of woody plants. It appears also that the area was subject to periodic droughts of sufficient length to produce very decided changes in the volume of large inland water bodies.

\section{MEASURED SECTIONS}

The following sections, measured by the writer and C. H. Dane, set forth in greater detail the lithologic character of the several parts of the Green River and Wasatch formations and their lateral variations. Beds described as low-grade oil shale yield less than 10 gallons' of oil to the ton.

\section{Sections of Tipton tongue of Green River formation in northern} part of Sweetwater County, Wyo.

Locality 1, sec. 1, T. 24 N., R. 100 W.

Shale, flaky, greenish gray; contains thin beds of ostracode limestone and abundant fish-bone fragments

Ostracode limestone; contains fish-bone fragments--

Shale, flaky to lumpy, brown to chrome-yellow.....

Interval concealed

Calcite parting, cone-in-cone structure

Shale, laminated, brown to greenish gray; contains a few thin beds of impure limestone.

Clay, olive-brown

Clay, greenish gray

Shale, flaky, greenish gray; alternates with brown laminated shale and thin beds of impure limestone.

Limestone, buff; contains abundant ostracodes, fishbone fragments, and clay balls.

Shale, flaky, greenish; alternates with brown paper shale and thin beds of sandy limestone; ostracodes numerous

Ft. in.

49

3

${ }_{16}$ Kellerman, K. F., Relation of bacteria to deposition of calcium carbonate: Science, new ser., vol. 41, pp. 507-508, 1915.

17 Idem, p. 508.
Limestone, sandy

Shale, flaky to laminated, greenish gray and brown.-

Limestone, finely crystalline, yellowish gray; contains . many mud balls and mud curls_..._._._._._._. 1

Interval concealed.............................. 3

Limestone, banded, hard

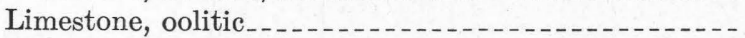

Shale, flaky, greenish gray _........................

Alga reef, mixed with sandy limestone

Shale and shaly limestone, laminated, gray ..........

Alga reef

Shale, flaky, greenish gray

Limestone, oolitic; contains mud curls.............

Shale, flaky to lumpy, gray green.........

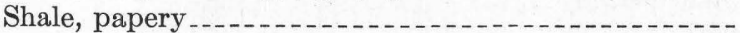

Limestone, dense, sandy; concretionary ..............

Shale, laminated, soft, limy, brown; ostracodes numerous; contains few beds of low-grade oil shale_._._ 12

Limestone, sandy and oolitic . .....................

Shale, alternately flaky and laminated, brown to gray; contains ostracodes.

Interval concealed, probably soft limy shale..........

Alga reef; ostracodes between the nodes..........

Shale, papery, bluish white

Limestone, platy; contains many large gastropods, Unios, and ostracodes.................... 3

Locality 2 , sec. 1, T. 23 N., R. 102 W.

Limestone, oolitic, thin bedded, buff; contains a few thin beds of sandy and limy shale............

Shale, platy, sandy, and limy

Shale, thin, uniform bedding, soft, grayish green.-.--

Alga reef, calcareous . . . . .......................

Sandstone, very fine grained, soft; contains thin beds of buff paper shale.

Alga reef, concentric shells of large stools and pillars 10 inches high and 2 to 5 inches in diameter; reef is slightly silicified.............................

Shale, papery, soft, light brown; contains small amount of low-grade oil shale_...........

Limestone, oolitic, in part almost unconsolidated; ostracodes abundant in lower few inches...........

Shale, laminated and papery; contains some beds of carbonaceous shale and small amount of low-grade oil shale_.

Ostracode-bearing limestone, thick beds, gray to buff_ Shale, papery, brown; replete with ostracodes . . . . . . Clay, soft, greenish gray ........................ Sandstone, clayey and limy, dark gray; bedding is very irregular and evidently indicates current or wave agitation at time of deposition.

Clay, light gray

Shale, flaky, soft, brown

Shale, laminated, hard, bluish gray; low-grade oil shale _.................................. Oolite; contains half-inch layer of alga deposit.......

Shale, laminated, blue-gray to buff; contains ostracodes....................

Alga reef

Shale, papery, blue-gray; low-grade oil shale........

Shale, papery; low-grade oil shale; contains numerous thin beds of ostracodes . . . Ostracode-bearing limestone, buff .................. Shale, papery, blue-gray; low-grade oil shale........Shale and ostracode-bearing limestone; consists of alternating thin beds of laminated shale and ostracodes.
Ft. in.

$$
5
$$


Ostracode-bearing limestone, stained with limonite; contains many fish-bone fragments and edgewise conglomerate of shale pieces

Shale, soft, gray; contains many ostracodes ........

Limestone, sandy, gray to faint buff; contains gastropods, ostracodes, and Unios.

Locality 3, sec. 25, T. 25 N., R. 102 W.

Shale, limy, white

Shale, papery

Limestone, banded, mud cracked

Shale, papery

Alga reef, marbleized.....

Shale, papery
Sandstone, cross-bedded on a small scale; contains beds of coarse angular quartz, grit, and stringers of small pebbles; bones of Parameryx and fish associated in the grits; beach deposit.

Interval concealed.................................

Clay, gray

Shale, limy, brown

Limestone, thin bedded, sandy, white . . . . . . . . .

Interval concealed

Limestone, thin bedded, sandy, white

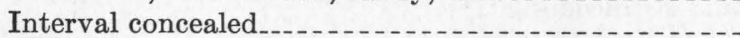

Shale, papery; contains thin beds of ostracode-bearing

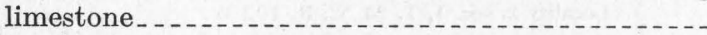

Limestone, massive; contains gastropods and ostracodes

Locality 4, sec. 18, T. 24 N., R. 102 W.

Top of bluff, approximately top of Tipton,tongue. Limestone, hard, yellow-brown to gray; in part ostracode-bearing limestone...................

Shale, sandy _.

Sandstone, crudely bedded, limy, fine grained, yellow-

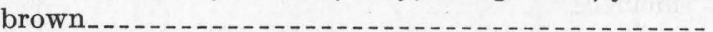

Sandstone, thin bedded, shaly, fine grained, gray

Sandstone, crudely bedded, hard, micaceous; contains large fragments of alga reef

Sandstone, platy, micaceous, very fine grained,

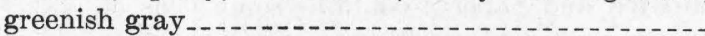

Alga reef; breaks into fragments resembling goose-egg shell

Shale, fissile, sandy and limy, micaceous, greenish

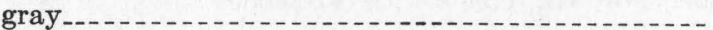

Limestone, porous, sandy; contains some ostracodes.-

Shale, papery, soft, yellowish brown

Shale, papery, slate-gray

Ostracode-bearing limestone, sandy, buff _..........

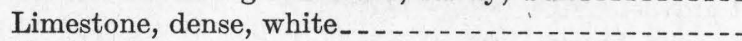

Sandstone, massive, fine grained, micaceous; contains round brown concretions and lenses of dark-brown grits which consist of angular grains of quartz and fresh feldspar

Shale, very sandy, platy, hard, gray

Sandstone, crudely bedded and cross-bedded, fine grained, micaceous, light gray to buff

Limestone, shaly, poorly bedded, hard, light gray to white. This zone persists through several townships surrounding this place.
Ft. in.

8

6

1

1159

Ft. in.

1

1

3

4

1

5

3

2

4

56

46

66

21

Shale, thin regular bedding, somewhat clayey, soft, brown to greenish gray . .................. Shale, papery, limy, soft, brown to buff Alga reef; large well-rounded stools_................ Shale, papery, soft, brown Alga reef Shale, flaky, very soft, brown to light gray _........ Ostracode-bearing limestone, buff ............... Shale, bedding obscure, sandy, light gray .......... Ostracode-bearing limestone................... Limestone, massive or platy, hard, rather coarsely crystalline, buff; contains abundant ostracodes.....-

Sandstone, limy, fine grained, hard ...........

Locality 5, sec. 18, T. 24 N., R. 103 W.

Sandstone, limy, thin bedded and cross-bedded, micaceous, white to yellowish gray .............

Sandstone, limy, soft; contains some oolite..........

Limestone, thin but very irregular bedding -........

Sandstone, limy, pale green; has a spherulitic texture due to grouping of sand grains.......... Sandstone, massive and cross-bedded, limy _.......... Limestone, poorly bedded, white Limestone and limy shale, white to yellowish gray.... Interval concealed . . . . . . . . . Ooilte, bedded; contains the fossil larval cases of trichopterous insects . . . . . .

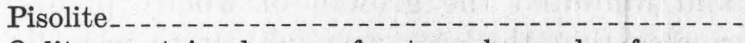
Oolite; contains layers of ostracodes and a few gastropods..........

Alga deposit; consists of an aggregate of small spheroidal lumps as much as 1 inch in diameter, which strongly resemble the so-called algoid lake balls of modern lakes

Limestone, clayey, light gray; contains abundant ostracodes . . . . . . .

Limestone, massive, hard, light gray; contains large quantities of ostracodes and near the top many gastropods.

Locality 6, sec. 25, T. 25 N., R. 103 w.

Sandstone, medium grained, thin regular bedding, limy, hard, light yellow-gray. Some of the thin beds are cross-bedded on a minute scale. Toward the top the sandstone becomes more massive and cross-bedding is more conspicuous ..................

Interval concealed _. . .

6 Shale, very sandy, thin bedded, gray _...........

6 Clay, soft, gray; alternates with thin beds of unconsolidated sand.................................

1 Clay, soft, limy, gray and brown Shale, very limy, thin bedded to papery, gray to brown Clay, laminated, light greenish gray ............... Alga reef; in part broken and recemented...........

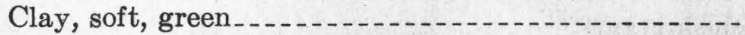
Limestone, oolitic, white to buff; contains great numbers of ostracodes and a few gastropods.......

Ostracode-bearing limestone, hard, buff; contains some oolites and many gastropods. .

\section{Ft. in. \\ 76 \\ $3 \quad 6$ \\ 2 \\ 10 \\ 1 \\ 14


Sections of Cathedral Bluffs tongue of Wasatch formation in northern part of Sweetwater County, Wyo.

Locality 7, sec. 21, T. 24 N., R. 101 W.

Top of ridge; approximate base of Morrow Creek member of Green River formation.

Clay, hard, gray

Clay, mauve...

Clay, hard, gray

Limestone; caliche (?)

Limestone,

Clay, hard, yellowish gray ........ 37

Clay, platy, hard, limy, gray _.......... 1

Clay, soft, gray to yellowish gray $\ldots \ldots \ldots$

Clay, hard, very limy; breaks into chips_._._._... 5

Sand, unconsolidated, yellowish gray_._._._._... 6

Clay, greenish gray; contains turtle-bone fragments _- 8

Clay, greenish gray; contains beds of reddish sandstone.

\begin{tabular}{rr}
$27 \quad 6$ \\
\hline 115
\end{tabular}

Locality 8, sec. 14, T. 25 N., R. 102 w.

Clay, carbonaceous, nearly black _..._.......... Clay, gray-green

Clay, irregularly platy, white

Clay, massive, hard, white

Clay, soft greenish gray, alternating with hard white

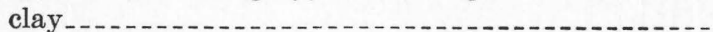

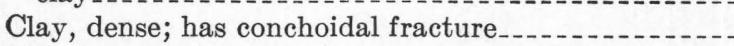

Clay, limy, white; breaks into flat chips . . . . .

Clay, light greenish gray

Clay, banded, dark and light greenish gray

Clay, hard, white, blocky fracture

Clay, dark greenish gray.

Interval concealed.

Clay, soft, gray; contains many isolated stools of calcareous alga reef

Clay, greenish gray

Clay, sandy, greenish gray

Sandstone, very friable, distinct but irregular bedding, light yellowish gray
Section of Morrow Creek member of Green River formation at locality 9, sec. 17, T. 23 N., R. 102 W., in northern part of Sweetwater County, Wyo.

Wyomingite flow capping Steamboat Mountain.

Shale, very limy, hard, platy

Ft. in.

(1).--

Pisolite, completely silicified....................

Sandstone, very fine grained, limy, gray to buff, regularly bedded.

Limestone, hard, slightly sandy, thin bedded, gray

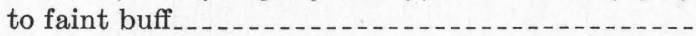

Shale, sandy, and fine-grained sandstone, brownish gray

Alga reef, completely silicified.

Sandstone, almost unconsolidated, medium to fine grained, gray; contains conspicuous amount of biotite

Limestone, shaly, hard, irregularly platy; carries plant impressions ............................ Sandstone, limy, fine grained, soft, buff banded with limonitic stain......... 15

Interval concealed, probably soft shaly sandstone_... 142

Limestone, sandy at base, grading upward into shaly limestone, ash-gray; carries abundant plant remains

Sandstone, almost unconsolidated, fine grained, buff-Sandstone, very limy, fine grained, irregularly bedded. Shale, flaky, crudely laminated, greenish gray . . . . ... Shale, very soft, paper-thin laminae, buff _.........Shale, finely laminated, light brown .............. Limestone, shaly, hard, irregularly bedded, buff......Shale, rather thick laminae, pale greenish gray ....... Shale, limy, soft, laminated; bedding planes wavy _...Clay, hárd, blocky, greenish buff_............. Limestone, shaly, irregularly bedded .............. Shale, soft, limy, paper-thin laminae; contains a few thin beds of low-grade oil shale_._._._._. 25

Shale, flaky, greenish gray _....... 5

Shale, papery, brown $\ldots$

Limestone, sandy Shale, carbonaceous, black; contains abundant plant fragments 